\title{
"Gendered perceptions of professional development in academia: evidence from a Ukrainian university"
}

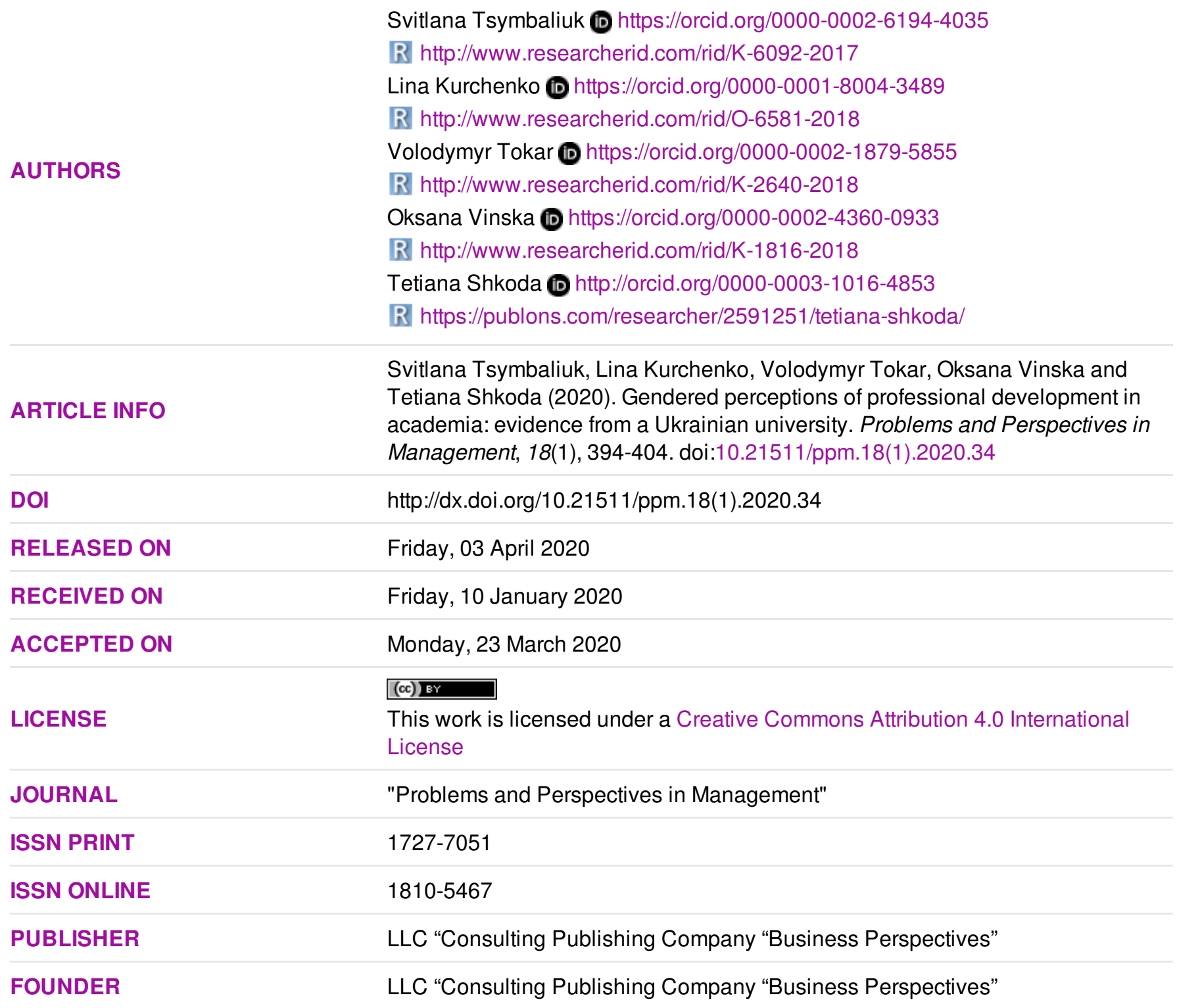

NUMBER OF REFERENCES

36

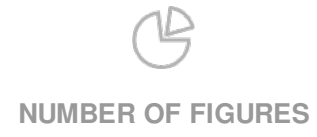

0
NUMBER OF TABLES

10

(C) The author(s) 2022. This publication is an open access article. 


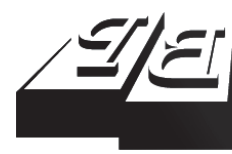

\section{BUSINESS PERSPECTIVES}

O

LLC "CPC "Business Perspectives" Hryhorii Skovoroda lane, 10, Sumy, 40022, Ukraine www.businessperspectives.org
Received on: $10^{\text {th }}$ of January, 2020 Accepted on: $23^{\text {rd }}$ of March, 2020 Published on: $3^{\text {rd }}$ of April, 2020

(๑) Svitlana Tsymbaliuk, Lina Kurchenko, Volodymyr Tokar, Oksana Vinska, Tetiana Shkoda, 2020

Svitlana Tsymbaliuk, Professor, Dean, Personnel Management, Sociology and Psychology Department, Kyiv National Economic University named after Vadym Hetman, Ukraine.

Lina Kurchenko, Associate Professor Department of German Language, Kyiv National Economic University named after Vadym Hetman, Ukraine.

Volodymyr Tokar, Professor, Department of International Finance, Kyiv National Economic University named after Vadym Hetman, Ukraine.

Oksana Vinska, Associate Professor, Department of European Economics and Business, Kyiv National Economic University named after Vadym Hetman, Ukraine.

Tetiana Shkoda, Associate Professor, Department of Personnel Management and Labor Economics, Kyiv National Economic University named after Vadym Hetman, Ukraine. (Corresponding author)
Svitlana Tsymbaliuk (Ukraine), Lina Kurchenko (Ukraine),

Volodymyr Tokar (Ukraine), Oksana Vinska (Ukraine), Tetiana Shkoda (Ukraine)

\section{GENDERED PERCEPTIONS OF PROFESSIONAL DEVELOPMENT IN ACADEMIA: EVIDENCE FROM A UKRAINIAN UNIVERSITY}

\begin{abstract}
The aim of the article is to study the impact of gender on the professional development of university teachers and their motivation for professional advancement. The article analyzes gendered perceptions of the professional development in the Ukrainian academic sector based on the survey of teachers from Kyiv National Economic University named after Vadym Hetman (KNEU) (Ukraine). The respondents provided their assessment of conditions that support or destroy their academic careers. The findings showed significant divergence in gendered perceptions and attitudes toward motives, conditions and results of professional development at the university. Although all staff members were unanimously confident in their professionalism, the degree of satisfaction, perception of fairness and willingness to engage in management through initiatives was significantly lower among women. Female academics expressed a greater need for mentoring, while men showed greater interest in material incentives. Impressively, $11 \%$ of women versus $0 \%$ of men believe that their gender is an obstacle to their career. The study findings require the inclusion of gender aspects in the university's development strategy and ensuring equal opportunities at all stages of HR management in academia.
\end{abstract}

\section{Keywords}

gender, academia, professional development, equal opportunities

JEL Classification I23, J16, J71

\section{INTRODUCTION}

Enhancing the role of women in academia and research is the EU's longterm goal and the focus of attention of the European Research Area (ERA). Recent monitoring results have shown that progress in achieving gender equality was particularly low. While Western European countries felt better than Central and Eastern European member states, the difference between member states and countries that are associated members was not significant (European Commission, 2017).

By signing the Association Agreement with the EU in 2017, Ukraine committed to bring its policies and standards in line with EU policies. The gender equality commitment is represented in the field of research under the EU Research and Innovation Programme Horizon 2020 (2014-2020), in which gender equality is a common goal. The expected impact is a critical mass of universities in Europe where gender equality plans are a tool for implementing institutional change (European Commission, 2019b). Gender-balanced teaching and management in higher education is an objective and priority of the EU Programme Erasmus+ for the period 2014-2020 (European Commission, 2019a).

Although gender policy is only just beginning to take shape in Ukraine, there is a solid legal and strategic framework for gender equality as 
provided by the Law of Ukraine "On Ensuring Equal Rights and Opportunities of Women and Men" (Parliament of Ukraine, 2005) and international commitments (UN Women Ukraine, 2019; UN Women, 1995; CEDAW, 1979). To support gender-responsive policies in academia and scientific research, it is important to investigate the gender aspect in academia and provide evidence for decision-making. This will promote steady academic development and foster convergence with the EU standards.

\section{LITERATURE REVIEW}

Gender issues are very important in academia as the vast majority of universities throughout the world tend to maintain the traditional type of gender representation in decision-making with a prevalence of men in top administrative and research positions (Savonick \& Davidson, 2018). Catalyst presents a lot of data on gender inequality in academia worldwide (Catalyst, 2017).

There is still a masculine image of science that needs to be overcome by social efforts and networking. According to EIGE, there were only 33\% women among European researchers in 2012 as compared to $47 \%$ female $\mathrm{PhD}$ graduates. It shows the need to encourage female scientists to pursue their careers (EIGE, 2016; ERA Portal, 2018).

The EU gender policies in academic management bring positive results. The percentage of female $\mathrm{PhD}$ graduates increased from $43 \%$ in 2004 to $47 \%$ in 2014. The percentage of women at the top level of a scientific career grew up from $18 \%$ in 2007 to $21 \%$ in 2013 . The percentage of female heads of universities increased from $15.5 \%$ in 2010 to $20 \%$ in 2014 . Recently, the number of women researchers has grown faster than that of men. Nevertheless, the percentage of women at the top level of an academic career is only $20 \%$, and the same figure applies to female university rectors (EIGE, 2016). It is noteworthy that amongst top rank researchers, women, as a rule, occupy a higher share of positions in the younger age category (49\%) compared with older ones (22\%) (EUODP, 2016).

The League of European Research Universities explores gender issues and perceptions in academia, including the latent gender discrimination as a challenge to the meritocratic rule and to women's careers, including academic recruitment, retention, advancement, and distribution of research funding (LERU, 2010, 2012, Buitendijk \& Maes, 2015, Gvozdanović \& Maes, 2018).
Gender awareness of researchers applying for Horizon 2020 funding significantly influences female participation and leadership in applicant teams. In category "A" projects, which seriously took into account gender issues based on content analysis, the representation of men and women was more equal than in other projects, and the percentage of female leaders exceeded the average by 10 percentage points ( $35 \%$ vs. $25 \%)$. The projects that did not consider gender issues were largely (84\%) managed by male leaders. The overall finding is as follows: the gender-related projects will perform better if the team includes gender experts (Cheveigné, Knoll, Bustelo, Engebretsen, \& Sandström, 2017).

GARCIA project participants explored "leaky pipeline" (i.e., consequent reduction of women's representation at each higher decision-making, management and income level) and "glass ceiling" (i.e., unconscious social convention on the upper limit of women's careers) in seven European countries. The "glass ceiling" is typically located at both the doctoral and postdoctoral levels, which indicates the difficulty of obtaining permanent positions. Female $\mathrm{PhD}$ holders have regular problems compared to male peers: higher likelihood of unemployment or part-time or fixed-term employment, less chances to complete research, as well as lower average wages (Dubois-Shaik \& Fusulier, 2015).

Previous studies consistently mirror both horizontal and vertical segregation by gender in academia. Women doctorate holders in socio-economic disciplines are still underrepresented in senior faculty positions and moderately represented at junior faculties in the USA. In four-year colleges and universities, women are less likely than men to be found in professorships and more likely to be assistant professors (Bilimoria \& Liang, 2014).

Greenwald, Banaji and Nosek (2015) investigated implicit social cognition. They developed an Implicit Association Test (IAT) to measure the 
strength of associations between concepts and evaluations or stereotypes. The IAT shows attitudes and beliefs that people may not report because of unwillingness or inability. The idea was that it is easier to make an answer when objects that are closely related share the same answer key. The IAT Gender-Career often reveals a relative link between career and males. The IAT GenderScience often demonstrates a relative connection between men and science, as well as between women and liberal arts (Project Implicit, 2018). Such IAT measurements prove that gender stereotypes, including those related to academic careers, are deeply embedded in our minds and operate on the subconscious level even if we believe the opposite.

Moss-Racusin, Dovidio, Brescoll, Graham, and Handelsman (2012) argue that female academics suffer from traumatic socialization as female students because of the implicit bias of teachers in favour of male students. Science faculties from universities assessed students' applications - who were haphazardly appointed female or male name - for the position of a head of laboratory. They made rating of male applicants as significantly more skilled and hired than the same female applicants (Moss-Racusin et al., 2012).

According to Etzkowitz, Kemelgor, and Uzzi (2009), successful female scientists tend to attribute their status and achievement to supportive mentors. However, they are often unsure and reluctant to take on risks of acting as mentors and advocates for their female students. In key moments of academic career decisions, young female scientists are often abandoned by potential female advisors as opposed to the well-connected male academic world.

Ragins and Cotton studied factors associated with perceiving barriers to mentoring and concluded that female respondents declared more barriers than mens (Ragings \& Cotton, 1991). However, networking and mentoring are critical to gaining leadership in postgraduate careers. For men, jobrank placement is predicted by the central place in the social community of the graduate-school-wide students, while for women a leadership position depends on both central place and the availability of a unique female narrow group in their social community (Yang, Chawla, \& Uzzi, 2019).
Guarino and Borden prove the existence of gender imbalance in faculty service load: women do more in terms of time and services. The excessive workload negatively affects teaching and research and leads to wage differences between women and men in academia (Guarino \& Borden, 2017).

Deiana (2017) discloses hidden costs of being a female academic based on results of interviews. Female interviewees believed that gender influenced their experience in academia, some of them commented positively on the presence of role models and mentors who give them advice and support. The respondents clearly stated a huge impact of motherhood and caring responsibilities on a women's career (Deiana, 2017).

Falkner, Szabo, Michell, Szorenyi, and Thyer (2015) have examined perceptions of female computer researchers with different backgrounds in Australia. The analysis revealed the impact of factors such as family, culture, network, gender bias and gendered thought, on their apperception, field, and their colleagues. The findings showed that even highly-efficient female experts had constant apperception of identity conflict and a lack of affiliation to the discipline (Falkner, Szabo, Michell, Szorenyi, \& Thyer, 2015).

Tzanakau (2017) views gender equality as a complex phenomenon that requires a constant and integral approach to address the following issues: stereotypes and gender patterns, lack of role models and mentors, and organizations that have gendered structures, assumptions and norms. The author points out that social science can play a vital role in understanding the inadequate female representation in scientific and educational institutions (Tzanakau, 2017).

Despite the ample literature on gender equality in academia, some aspects of this problem require further in-depth study. First, a case study approach enables researchers to delve into details and find meaningful interrelations. Second, researchers often describe gender-diversified academic environment, but do not into account differences in the perception of challenges and responsibilities by men and women. This study is aimed at identifying differences and similarities between female 
and male answers to questions that are crucial for improving educational environment not only in Ukraine, but also, possibly, in other countries. This research reveals perceptions and motivation for professional development in academia, taking into account the gender of respondents.

\section{AIMS}

The aim of this article is to study the impact of gender on the professional development of university teachers and their motivation for professional advancement.

\section{DATA AND METHODS}

The working hypothesis of this study is based on the assumption that a substantial part of the professional and scientific potential of the $\mathrm{KNEU}$ is not utilized due to gender imbalance. A significant part of the university teachers and professors are presumably not satisfied with the realization of their professional potential. Hence, the existing hiring, training and staff development policies, as well as programs for teachers' engagement in research, innovation and international academic mobility need some improvements in terms of ensuring equal opportunities for both women and men.

To confirm or reject the working hypothesis, in September 2019 - November 2019, a sociological survey in the form of an anonymous questionnaire was conducted. The questionnaire was designed by a multidisciplinary research team to cover multifaceted academic activities and perceptions from the gender perspective. The purpose of the survey was, based on gendered perceptions of the respondents, to examine intentions of the staff towards professional development and conditions that contribute to individual's professional development in the academic environment.

The objectives of the survey included:

- exploring intentions of teaching staff regarding professional development and confidence in their own professionalism;
- evaluating the level of employees' satisfaction with their potential realization and recognition of their achievements;

- finding out conditions that contribute to or impede professional development of teachers;

- assessing teachers' needs for coaching and mentoring aimed at professional development;

- justifying the necessity of considering gender aspects to create supportive conditions for an individual's professional development in the academic environment.

The survey audience was the KNEU's academic teaching staff. As of September 1, 2019, the total academic teaching staff amounted to 1,097 teachers and professors (further jointly referred to as teachers), including 755 women, i.e. $69 \%$.

To calculate a relevant sample size, the modification of the Cochran's formula for sample size calculation in smaller populations was used (Barlett, Kotrlik, \& Higgins, 2001). The required sample size for the total population of $N=1097$ people and $5 \%$ accuracy is 285 .

Two hundred and eighty-five (285) teachers and professors (69\% female and 31\% male) took part in the survey that provided representativeness. The difference of more than $5 \%$ can be considered as essential. Due to the large amount of the total population and the relative homogeneity of units for the total population, the simple random sample method was chosen. Data were obtained via paper-and-pencil questionnaire administration. The questionnaire contained closed multiple-choice questions with the option to mark the respondent's perception on a 5-grade scale; also the examples were given to explain questions. All faculty members were contacted by e-mail. Each teacher and professor had an equal opportunity to participate in the survey. Questionnaires were filled out voluntarily and anonymously in paper and collected without contacting the researchers. Data were analyzed and published in a generalized gender-disaggregated form. Thus, the respondents' confidentiality was secured. Table 1 shows the distribution of respondents by gender, position, academic degree and years of teaching practice. 
Table 1. Distribution of respondents by positions, academic degree, years of teaching practice and gender

Source: Constructed by the authors.

\begin{tabular}{|c|c|c|c|c|}
\hline \multirow[t]{2}{*}{ Characteristics } & \multicolumn{2}{|c|}{$\begin{array}{c}\text { Female } \\
\text { respondents }\end{array}$} & \multicolumn{2}{|c|}{$\begin{array}{c}\text { Male } \\
\text { respondents }\end{array}$} \\
\hline & \multicolumn{2}{|c|}{ Number Share, \% } & Number & Share, \% \\
\hline \multicolumn{5}{|c|}{ Position } \\
\hline Assistant & 16 & 8 & 8 & 9 \\
\hline Lecturer & 2 & 1 & 0 & 0 \\
\hline Senior lecturer & 26 & 13 & 9 & 10 \\
\hline Associate professor & 115 & 58 & 36 & 41 \\
\hline Professor & 22 & 11 & 22 & 25 \\
\hline $\begin{array}{l}\text { Deputy head of a } \\
\text { department }\end{array}$ & 7 & 4 & 2 & 2 \\
\hline Head of a department & 7 & 4 & 6 & 7 \\
\hline Deputy dean & 1 & 1 & 1 & 1 \\
\hline $\begin{array}{l}\text { Dean (director of an } \\
\text { institute) }\end{array}$ & 1 & 1 & 4 & 5 \\
\hline Total & 197 & 100 & 88 & 100 \\
\hline \multicolumn{5}{|c|}{ Academic degree } \\
\hline $\begin{array}{l}\text { Academic degree } \\
\text { lower than Ph.D. }\end{array}$ & 65 & 33 & 23 & 26 \\
\hline Ph.D. & 114 & 58 & 44 & 50 \\
\hline $\begin{array}{l}\text { Doctor of Science (Dr. } \\
\text { Habil.) }\end{array}$ & 18 & 9 & 21 & 24 \\
\hline Total & 197 & 100 & 88 & 100 \\
\hline \multicolumn{5}{|c|}{ Years of teaching practice } \\
\hline Under 3 years & 13 & 7 & 3 & 3 \\
\hline $\begin{array}{l}\text { From } 3 \text { to } 10 \text { (incl.) } \\
\text { years }\end{array}$ & 43 & 22 & 12 & 14 \\
\hline $\begin{array}{l}\text { From } 10 \text { (excl.) to } 20 \\
\text { years }\end{array}$ & 77 & 39 & 38 & 43 \\
\hline Over 20 years & 64 & 32 & 35 & 40 \\
\hline Total & 197 & 100 & 88 & 100 \\
\hline
\end{tabular}

\section{RESULTS}

As of September 1, 2019, the total academic teaching staff of the KNEU amounted to 1,097 (69\% of women and $31 \%$ of men). This gender distribution roughly complies with the overall situation in the Ukrainian education sector, where women account for 78\% of the workforce (Duban \& Suslova, 2017). Female over-representation corresponds to low wages in the Ukrainian education sector, which were $23 \%$ lower than the total national average by the 4 th quarter 2018 (SSSU, 2018). In the international context, when women represented $41.9 \%$ in tertiary education in 2017, countries like Azerbaijan, Armenia, Georgia, Belarus, Russia, and Moldova show a representation of women - 54-58\% (World Bank, 2019).

The statistical analysis of data on women and men holding senior positions at KNEU led to the following findings. The total share of women in leadership positions (heads and deputy heads of departments, deans and rector) is $56 \%$ (or 86 out of 153) (Table 2).

In terms of the rector's office (a top management level), women account for only $29 \%$ (2 out of 7 members). At the middle management level, only one (11\%) of 9 deans is a woman (Table 3 ).

The situation shifts to the opposite at the deputy dean level, where women account for $74 \%$ (14 out of 19). Amongst 56 department heads, who represent the lower management level, there are 22 women $(39 \%)$. The deputy department head level is mainly represented (76\%) by women (47 out of 62). Thus, KNEU has the traditional male-domi-

Table 2. Gender dimension of management at KNEU (unit heads and deputy heads)

Source: Constructed by the authors based on the KNEU's official website (Vinska \& Tokar, 2018).

\begin{tabular}{|c|c|c|c|c|c|c|}
\hline Indicator & Females & Males & Total & Share of women, \% & Share of men, \% & Total, \% \\
\hline Rector's office & 2 & 5 & 7 & 29 & 71 & 100 \\
\hline Deans' offices & 15 & 13 & 28 & 54 & 46 & 100 \\
\hline Departments & 69 & 49 & 118 & 58 & 42 & 100 \\
\hline Total & 86 & 67 & 153 & 56 & 44 & 100 \\
\hline
\end{tabular}

Table 3. Gender dimension of management of deans' offices at KNEU

Source: Constructed by the authors based on the KNEU's official website (Vinska \& Tokar, 2018).

\begin{tabular}{|c|c|c|c|c|c|c|}
\hline Indicator & Females & Males & Total & Share of women, \% & Share of men, \% & Total, \% \\
\hline Deans & 1 & 8 & 9 & 11 & 89 & 100 \\
\hline Deputy deans & 14 & 5 & 19 & 74 & 26 & 100 \\
\hline Total & 15 & 13 & 28 & 54 & 46 & 100 \\
\hline
\end{tabular}


nated type of the decision-making process, as the majority of unit heads at all management levels are men, while women are engaged in the process of preparing draft ideas for them to consider (Vinska \& Tokar, 2018).

According to the survey results, both men and women in KNEU have shown the same interest (with the exception of several teachers) in their intention for professional development. Table 4 shows the answers of the KNEU teachers about their desire for professional development.

Table 4. The respondents' answers to the question "Do you seek professional development?"

Source: Constructed by the authors.

\begin{tabular}{l|c|c}
\hline \multirow{2}{*}{ Multiple choice } & \multicolumn{2}{|c}{ Share of respondents, \% } \\
\cline { 2 - 3 } & Women & Men \\
\hline Yes & 86 & 86 \\
\hline Rather yes & 10 & 14 \\
\hline Difficult to say & 3 & 0 \\
\hline Rather no & 1 & 0 \\
\hline No & 0 & 0 \\
\hline Total & 100 & 100 \\
\hline
\end{tabular}

The vast majority of respondents $(96 \%$ of women and $100 \%$ of men) noted that they desired professional development. The teachers constitute a strategic resource for the university, so it is important to create conditions for maximizing employees' potential and to support their professional development at the university.

Given the high level of the desire of the teaching staff for professional development, it is necessary to find out:

- whether employees are confident in their professionalism;

- whether there are equal opportunities for the professional development of staff at the university;

- whether there are conditions that hamper the actualization of the teaching staff's potential and their professional development.

Being confident in your own professionalism means knowing your own professional skills, strengths and advantages, the contribution you make, the value you provide, and acting in a way that transfers that to people around you. Table 5 shows the KNEU teachers' answers to the question "Are you confident in your professionalism?"

Table 5. Respondents' answers to the question "Are you confident in your professionalism?"

Source: Constructed by the authors.

\begin{tabular}{l|c|c}
\hline \multirow{2}{*}{ Multiple choice } & \multicolumn{2}{|c}{ Share of respondents, \% } \\
\cline { 2 - 3 } & Women & Men \\
\hline Yes & 62 & 65 \\
\hline Rather yes & 30 & 35 \\
\hline Difficult to say & 7 & 0 \\
\hline Rather no & 1 & 0 \\
\hline No & 0 & 0 \\
\hline Total & 100 & 100 \\
\hline
\end{tabular}

The distribution of respondents' answers about their confidence in their own professionalism between men and women turned out to be different. According to the survey results, men are more confident in their professionalism than women. All men (100\%) have chosen "Yes" or "Rather yes", while $7 \%$ of women found it difficult to say, and $1 \%$ of women said that they were not confident in their professionalism. Thus, women's uncertainty has to be highlighted as an important career-adverse psychological factor: firstly, this can lead to fewer women applying for higher academic positions and grades, and secondly, ceteris paribus, it puts women at disadvantage compared to self-confident men.

Table 6 displays the KNEU teachers' answers about their satisfaction with the realization of their professional potential.

Table 6. The respondents' answers to the question "Are you satisfied with the realization of your professional potential?"

Source: Constructed by the authors.

\begin{tabular}{l|c:c}
\hline \multirow{2}{*}{ Multiple choice } & \multicolumn{2}{|c}{ Share of respondents, \% } \\
\cline { 2 - 3 } & Women & Men \\
\hline Yes & 20 & 24 \\
\hline Rather yes & 33 & 36 \\
\hline Difficult to say & 17 & 17 \\
\hline Rather no & 25 & 17 \\
\hline No & 5 & 6 \\
\hdashline Total & 100 & 100 \\
\hline
\end{tabular}


The results have shown differences in the satisfaction of men and women with their professional self-actualization. $60 \%$ of men gave positive answers concerning the actualization of their professional potential, while the respective percentage of women was lower, $53 \%$. Meanwhile, $30 \%$ of women are completely or rather dissatisfied with the actualization of their professional potential; the percentage of dissatisfied men is lower (23\%).

In general, the research results have indicated low teachers and professors' satisfaction with their potential actualization, given their desire for professional development and relatively high indicators of confidence in their professionalism, especially among men. It can be concluded that the university has no conditions for professional development and realization of potential by the teaching staff, which confirms one of the hypotheses.

The fact that only about half of women are satisfied with the current state of things indicates a significant hidden reserve for staff development; it also shows women's systemic disparities relative to men. One can confirm that the university does not sufficiently implement the principle of creating equal opportunities for the academic staff development. This confirms, to a certain extent, another hypothesis that it is necessary to improve the processes of hiring, training, development of teaching staff, their engagement in scientific, innovative activities and international academic mobility programs in terms of creating equal opportunities for women and men.

Given the recognition issues, a significant part of men and women do not feel their achievements are adequately recognized: $39 \%$ of women gave a negative answer, while men were less negative with 27\% (Table 7).
The results of the survey have indicated significant problems in the university's staff management policy. Given the employees' desire for professional development, the dissatisfaction of about one third of them with recognition of their achievements may lead not only to decrease in motivation, but also to lower loyalty to the university. This, in return, can cause a high staff turnover that may result in the loss of human capital and hiring unmotivated and disloyal employees at the university. It can also cause the reduced quality of educational activities and decrease the university's reputation in the education market. It should be recommended to investigate the causes of professional dissatisfaction applying gender approach and bearing in mind that women account for more than two thirds of the teaching staff and demonstrate a higher grade of dissatisfaction and perceived insufficiency of acknowledgement compared to men.

Given the low level of compensation in the Ukrainian education sector, it is important to find out whether dissatisfaction of teachers with the recognition of their achievements concerns material or immaterial benefits and to which extent the prevalence of material and immaterial factors correlates with gender.

Despite the fact that more women expressed their dissatisfaction with the recognition of their achievements as compared to men, the survey results have indicated that significantly more men (80\%) than women $(63 \%)$ feel their activities need to be approved by their social environment. More men (46\%) than women (40\%) expressed the need for non-financial reward (e.g., certificate of acknowledgment, certificate of achievement, honorary title, publicity, etc.). These unexpected findings indicate that male teachers are more sensitive to social approval and immaterial signs of acknowledgement than women.

Table 7. Respondents' answers to the question "Do you think your achievements are adequately recognized?"

Source: Constructed by the authors.

\begin{tabular}{|c|c|c|}
\hline \multirow{2}{*}{ Multiple choice } & \multicolumn{2}{|c|}{ Share of respondents, \% } \\
\hline & Women & Men \\
\hline Yes & 11 & 9 \\
\hline Rather yes & 27 & 32 \\
\hline Difficult to say & 23 & 32 \\
\hline Rather no & 27 & 18 \\
\hline No & 12 & 9 \\
\hline Total & 100 & 100 \\
\hline
\end{tabular}


As already mentioned, the vast majority of teachers, regardless of gender, have explicitly indicated their desire for professional development, so it is important to find out whether they need guidance and support (e.g., coaching, mentoring) for their professional development. The percentage of men $(39 \%)$ who need coaching or mentoring for their professional development is lower than the respective percentage of women (45\%). Interestingly, only $36 \%$ of female respondents pointed out that they definitely or probably did not need coaching for their professional development, while among men the number of negative responses was significantly higher (50\%). Thus, in the course of professional advancement, women need more guidance and support, while men need more approval and acknowledgement for their independent actions.

According to the survey results, during meetings or other official events men feel freer to openly express their ideas of how to improve academic environment. 89\% of male respondents have chosen positive answers on their willingness to openly express their ideas, while the percentage of women is lower $-80 \%$.

Male respondents showed not only willingness to openly express their ideas, but also more engagement in their own initiatives related to improving the academic environment and professional activity. $85 \%$ of men versus $80 \%$ of women answered that they turned to management to present their initiatives. The $5 \%$ difference in male and female respondents' answers is within the trust interval for the calculations. It means that women and men demonstrate almost equal engagement in their own initiatives related to improving the academic environment and professional activity; but since women are more often hesitant to express their ideas to the public, they may seem less interested and less active than men.

Given the fact that a significant percentage of women are dissatisfied with the actualization of their professional potential (30\%) and express the need for coaching or mentoring for their professional development (45\%), implementing such advancement support programs could foster the professional development of female teachers, raise their confidence and self-esteem and unfold their professional potential and initiative to the university's advantage.

The respondents' answers to the question "Do you have an ambition to become a manager?" are displayed in Table 8 . The survey results show that $39 \%$ of male respondents have an ambition to become a manager, while the percentage of women is significantly lower $-28 \% .47 \%$ of female respondents do not want to hold an administrative position, while the percentage of men who do not desire to be a manager is lower - at $39 \%$.

Table 8. Respondents' answers to the question "Do you have an ambition to become a manager?"

Source: Constructed by the authors.

\begin{tabular}{l|c:c}
\hline \multirow{2}{*}{\begin{tabular}{l} 
Multiple choice \\
\cline { 2 - 3 }
\end{tabular}} & Share of respondents, \% \\
\cline { 2 - 3 } & Women & Men \\
\hline Yes & 9 & 16 \\
\hline Rather yes & 19 & 23 \\
\hline Difficult to say & 25 & 22 \\
\hline Rather no & 30 & 18 \\
\hline No & 17 & 21 \\
\hline Total & 100 & 100 \\
\hline
\end{tabular}

The unwillingness of a significant part of women to hold administrative positions may have several social and personal reasons. Social reasons can be objective (e.g., family circumstances) and subjective (e.g., rejection of a female manager by the academic environment). Personal reasons can also be objective (e.g., state of health) and subjective (low self-esteem, lack of confidence in own competence). Therefore, it is important to create appropriate conditions to fully use the professional potential of the female staff, in particular changing the perception of a female manager by the academic environment. It is important to implement educational programs for developing leadership capacity, self-esteem and self-confidence of both women and men.

In the final and most convincing accord, $11 \%$ of women have noted that their sex (gender) impeded their career growth, while none of the male respondents has chosen "yes" or "rather yes" as shown in Table 9. 
Table 9. Respondents' answers to the question "Do you think your gender impedes your career development?"

Source: Constructed by the authors.

\begin{tabular}{l|c|c}
\hline \multirow{2}{*}{ Multiple choice } & \multicolumn{2}{|c}{ Share of respondents, \% } \\
\cline { 2 - 3 } & Women & Men \\
\hline Yes & 3 & 0 \\
\hline Rather yes & 8 & 0 \\
\hline Difficult to say & 11 & 6 \\
\hline Rather no & 25 & 4 \\
\hline No & 53 & 90 \\
\hline Total & 100 & 100 \\
\hline
\end{tabular}

$19 \%$ of all respondents (equally male and female) believe that men have the privilege of obtaining top positions (Table 10), which indicates how deeply social stereotypes and misconceptions about the role of men and women in academia are assimilated into teachers' minds regardless of their gender.

Table 10. Respondents' answers to the question "Do you think men should have the privilege of obtaining top positions?"

Source: Constructed by the authors.

\begin{tabular}{l|c|c}
\hline \multirow{2}{*}{ Multiple choice } & \multicolumn{2}{c}{ Share of respondents, \% } \\
\cline { 2 - 3 } & Women & Men \\
\hline Yes & 8 & 6 \\
\hline Rather yes & 11 & 13 \\
\hline Difficult to say & 8 & 14 \\
\hline Rather no & 13 & 12 \\
\hline No & 60 & 55 \\
\hline Total & 100 & 100 \\
\hline
\end{tabular}

This confirmed the hypothesis that it is necessary to implement and disseminate an equal opportunity policy in the academic environment, especially in relation to professional development, taking into account gender factors and career growth.

\section{DISCUSSION}

Having analyzed the gendered perceptions of a random sample of teachers at KNEU as of September 2019 - November 2019, the study showed that only $78 \%$ of female teachers, unlike $94 \%$ of men, do not perceived their gender as an obstacle to their professional development, while $11 \%$ of women and not a single man considered their gender to be an unfavorable career factor. $19 \%$ of all respondents (equally male and female) consider that men have the privilege of getting top positions, so gender stereotypes are equally intrinsic to both sexes. This is evidence of gender bias in HR policy in Ukrainian academia based on social stereotypes. Given the overwhelming majority of women in university teaching staff in KNEU, in the country and in the region, this situation calls for some measures in terms of creating and communicating equal opportunities for professional growth of women and men.

Men in academia demonstrate a higher grade of confidence in their professionalism and higher satisfaction with actualization of their professional potential. They are more ambitious about management positions and more willing to express their ideas to the public. At the same time, men are definitely more dependent on social approval of their actions and express more interest in non-financial reward compared to women.

Women in academia are less self-confident, they are more reluctant to express their ideas and initiatives to the public; $39 \%$ of women are dissatisfied with the level of recognition of their professional effort. Surprisingly, women have demonstrated more independence of external approval of their actions than men, but in parallel they clearly appreciate more guidance and support in the form of coaching and mentoring. It can be concluded that gender stereotypes, relatively low self-esteem and the lack of recognition and reward impede the academic advancement of women.

\section{CONCLUSION}

The results of research showed that teachers, both women and men, showed almost equally high degree of motivation for professional development, their desire to advance is a significant unexplored development driver for the university. However, given the inconsistency of gender perceptions in the scientific 
community, this potential can be used more effectively if strategies and policies that take into account gender aspects are implemented. These may include the identification on gender stereotypes, promotion of positive female academic role models, introducing women-oriented training, mentoring and coaching, gender-disaggregated monitoring of professional performance to identify female talents, gender-responsive management, budgeting, recruitment and advancement policies, and sustainable setting of equal opportunity goals in academia.

Summing up the outcomes of this research, one should emphasize the importance of gender aspects in professional activities in the academic environment, in particular in the KNEU as a typical Ukrainian university. There are both personal and social factors contributing to professional development of the teaching staff. Gender aspects determine the success of teaching and research activities, and therefore require in-depth study and consideration when shaping a university development strategy.

\section{AUTHOR CONTRIBUTIONS}

Conceptualization: Svitlana Tsymbaliuk, Volodymyr Tokar.

Data curation: Lina Kurchenko, Volodymyr Tokar.

Formal analysis: Svitlana Tsymbaliuk, Oksana Vinska.

Funding acquisition: Lina Kurchenko, Volodymyr Tokar.

Investigation: Svitlana Tsymbaliuk, Lina Kurchenko, Volodymyr Tokar, Oksana Vinska, Tetiana Shkoda. Methodology: Svitlana Tsymbaliuk, Volodymyr Tokar.

Project administration: Svitlana Tsymbaliuk, Tetiana Shkoda.

Resources: Lina Kurchenko, Tetiana Shkoda.

Software: Volodymyr Tokar.

Supervision: Svitlana Tsymbaliuk.

Validation: Volodymyr Tokar, Oksana Vinska.

Visualization: Oksana Vinska, Tetiana Shkoda.

Writing - original draft: Lina Kurchenko, Tetiana Shkoda.

Writing - review \& editing: Lina Kurchenko, Tetiana Shkoda.

\section{REFERENCES}

1. Barlett, J., Kotrlik, W., \& Higgins, C. (2001). Organizational Research: Determining Appropriate Sample Size in Survey. Retrieved from https://www.researchgate. net/publication/200824035_Organizational_Research_Determining_Appropriate_Sample_Size_in_ Survey_Research

2. Bilimoria, D., \& Liang, X. (2014). State of Knowledge about the Workforce Participation, Equity, and Inclusion of Women in Academic Science and Engineering. Women, Science, and Technology: a Reader in Feminist Science Studies (pp. 21-50). New York, Routledge, NY.

3. Buitendijk, S., \& Maes, K. (2015). Gendered Research and Innovation: Integrating Sex and Gender
Analysis into the Research Process. Retrieved from https://www.leru. org/files/Gendered-Research-andInnovation-Full-paper.pdf

4. CATALYST (2019). Quick Take: Women in Academia. Retrieved from https://www.catalyst.org/ research/women-in-academia/

5. CEDAW (1979). Convention on the Elimination of All Forms of Discrimination against Women. Resolution of UN General Assembly adopted on 18 December 1979. Retrieved from https://www.un.org/ womenwatch/daw/cedaw/

6. Cheveigné, S., Knoll, B., Bustelo, M., Engebretsen, E., \& Sandström, U. (2017). Interim evaluation: Gender equality as a crosscutting issue in Horizon 2020. Retrieved from https://ec.europa.eu/research/ swafs/pdf/pub_gender_equality/ interim_evaluation_gender_long_ final.pdf

7. Deiana, M. A. (2017). Research Report: Hidden Costs of Being a Female Academic. Retrieved from https://www.qub.ac.uk/

8. Duban, E., \& Suslova, O. (2017). Gender Analysis Report. Kyiv: USAID/Ukraine.

9. Dubois-Shaik, F., \& Fusulier, B. (ed.) (2015). Academic Careers and Gender Inequality: Leaky Pipeline and Interrelated Phenomena in Seven European Countries. Trento: University of Trento.

10. EIGE (2016). Gender Equality in Academia and Research. Gear Tool. Retrieved from https://eige. europa.eu/gender-mainstreaming/ 
toolkits/gear/objectives-genderequality-research

11. ERA Portal Austria (2018). The Knowledge-Sharing Platform. Retrieved from https://era.gv.at/

12. Etzkowitz, H., Kemelgor, C., \& Uzzi, B. (2009). Athena Unbound: The Advancement of Women in Science and Technology. Cambridge: Cambridge University Press. https://doi.org/10.1017/ CBO9780511541414

13. EUODP (2016). SHE Figures 2015 EU Open Data Portal, European Union, Luxembourg. Retrieved from https://op.europa.eu/en/ publication-detail/-/publication/f546dfed-41a9-11e6-af3001aa75ed71al

14. European Commission (2017) ERA Progress Report 2016. European Union, Luxembourg, https:// doi.org/10.2777/992170

15. European Commission (2018). Guidance to Facilitate the Implementation of Targets to Promote Gender Equality in Research and Innovation. Retrieved from https:// ec.europa.eu/research/swafs/pdf/ pub_gender_equality/KI-07-17199-EN-N.pdf

16. European Commission (2019a). Erasmus + Funding Programme. Retrieved from https://ec.europa. eu/info/education/set-projectseducation-and-training/erasmusfunding-programme_en

17. European Commission (2019b). Promoting Gender Equality in Research and Innovation. Retrieved from https://ec.europa.eu/ programmemes/horizon2020/en/ h2020-section/promoting-genderequality-research-and-innovation

18. Falkner, K., Szabo, C., Michell, D., Szorenyi, A., \& Thyer, S. (2015). Gender Gap in Academia: Perceptions of Female Computer Science Academics. ITiCSE '15: Proceedings of the 2015 ACM Conference on Innovation and Technology in Computer Science Education (pp. 111-116). https://doi. org/10.1145/2729094.2742595

19. Greenwald, A. G., Banaji, M. R., \& Nosek, B. A. (2015). Statistically small effects of the Implicit Association Test can have societally large effects. Journal of Personality and Social Psychology, 108(4), 553-561. https://doi. org/10.1037/pspa0000016

20. Guarino, C., \& Borden, V. (2017). Faculty Service Loads and Gender: Are Women Taking Care of the Academic Family? Research in Higher Education, 58, 672-694. Retrieved from http://ftp.iza.org/ dp10010.pdf

21. Gvozdanović, J., \& Maes, K. (2018). Implicit Bias in Academia. Retrieved from https://www.leru. org/files/implicit-bias-in-academia-full-paper.pdf

22. LERU (2010). Harvesting Talent: Strengthening Research Careers in Europe 28.01.2010. Retrieved from https://www.leru.org/news/ harvesting-talent-strengtheningresearch-careers-in-europe

23. LERU (2012). Women, Research and Universities: Excellence without Gender Bias. Retrieved from https://www.leru.org/files/ Women-Research-and-Universities-Excellence-without-GenderBias-Executive-summary.pdf

24. Moss-Racusin, C. A., Dovidio, J. F., Brescoll, V. L., Graham, M. J., \& Handelsman, J. (2012). Science faculty's subtle gender biases favor male students. In S. Tilghman (Ed.), Proceedings of the NAS, USA, October 9, 2012, 109(41), 1647416479. https://doi.org/10.1073/ pnas. 1211286109

25. Parliament of Ukraine (2005). Law of Ukraine on Ensuring Equal Rights and Opportunities of Women and Men, September 8, 2005, No. 2866. (In Ukrainian). Retrieved from https://zakon.rada. gov.ua/laws/show/2866-15

26. Project Implicit. (2018). Retrieved from https://implicit.harvard.edu/ implicit/iatdetails.html

27. Ragins, B. R., \& Cotton, J. L. (1991). Easier Said than Done: Gender Differences in Perceived Barriers to Gaining a Mentor. Academy of Management Journal, 34(4), 939-951. https://doi. org/10.5465/256398

28. Savonick, D., \& Davidson, C.N. (2018). Gender Bias in Academe: An Annotated Bibliography of
Important Recent Studies. Retrieved from https://www.hastac.org/blogs/ superadmin/2015/01/26/genderbias-academe-annotated-bibliography-important-recent-studies

29. SSPERO. (2018). State Social Programme on Equal Rights and Opportunities of Women and Men for the period up to 2021. CMU Resolution No 273, 11 April 2018, Kyiv.

30. SSSU. (2018). State Statistic Service of Ukraine: Monthly Average Wages by Economic Activities, Quarterly Data 2018. (In Ukrainian). Retrieved from http://www.ukrstat. gov.ua/

31. SSSU. (2019). State Statistic Service of Ukraine: Education - Higher Education Institutions. (In Ukrainian). Retrieved from http://www. ukrstat.gov.ua/

32. Tzekanau, C. (2017). Gender Equality in Higher Education: A View from a Social Scientist. Retrieved from https://womeninhpc.org/ diversity-and-inclusion/genderequality-in-higher-education-aview-from-a-social-scientist

33. UN Women (1995). Action for Equality, Development and Peace: Platform for Action. Fourth World Conference on Women, Beijing, September 1995.

34. Vinska, O., \& Tokar, V. (2018). The Compliance with the EU Value of Gender Equality in Ukrainian Universities: Does the Glass-Ceiling Exist in KNEU? European Integration Processes in the XXI Century. Key Tendencies, Main Challenges and New Opportunities Conference proceedings, 26-27 March 2018, Kyiv, pp. 69-76.

35. World Bank. (2019). Tertiary Education, Academic Staff (\% Female). Retrieved from https://data.worldbank.org/indicator/SE.TER.TCHR. FE.ZS? end $=2013$ andstart $=1970$ and view $=$ chart

36. Yang, Y., Chawla, N.V., \& Uzzi, B. (2019). A Network's Gender Composition and Communication Pattern Predict Women's Leadership Success. Proceedings of the NAS USA, 22 January 2019. Retrieved from https://www.pnas. org/content/116/6/2033 